\title{
Teachers in The New Normal: Challenges and Coping Mechanisms in Secondary Schools
}

\author{
Aina Joyce D. Agayon ${ }^{1,2}$, Angel Kem R. Agayon ${ }^{1,2}$, Jupeth T. Pentang ${ }^{2 *}$ \\ ${ }^{1}$ Barotuan National High School, El Nido Del Norte District, Palawan Philippines \\ Email: ainajoyce.dichos@ deped.gov.ph, angelkem.agayon@deped.gov.ph \\ ${ }^{2}$ College of Education, Western Philippines University, Puerto Princesa City, Philippines \\ Email: jupeth.pentang@wpu.edu.ph \\ *correspondence
}

Received: 15 Dec 2021; Received in revised form: 18 Jan 2022; Accepted: 27 Jan 2022

(C)2022 The Author(s). Published by TheShillonga. This is an open access article under the CC BY license (https://creativecommons.org/licenses/by/4.0/)

\begin{abstract}
Teachers encountered numerous challenges posed by the COVID-19 outbreak. Herewith, this study aimed to determine the challenges encountered by Filipino teachers in the new normal and their coping mechanisms. This study employed a qualitative inquiry to determine the challenges encountered and coping mechanisms employed by teachers amid modular instruction, involving 10 teachers from five secondary schools in the Philippines who participated voluntarily. Data were gathered through a written narrative from each participant and were analyzed thematically. Themed findings showed that these teachers are greatly challenged in terms of learning quality transfer, module distribution and retrieval, students' difficulties in following instruction, power disruption, internet connection, and health risks posed by the pandemic. Nevertheless, these teachers dealt with these difficulties by employing their own coping techniques. Teaching can be challenging and frustrating, especially in these difficult times, but as these teachers demonstrated, everything is possible. Hence, educators must be ready for any situation that may arise. This situation is unlikely to get better anytime soon; instead, teachers will need to adjust to and accept this reality.
\end{abstract}

Keywords_challenges, coping mechanisms, COVID-19 pandemic, Filipino teachers, modular instruction.

\section{INTRODUCTION}

The coronavirus disease 2019 (COVID-19) pandemic continuously impacts educational systems around the world and this paradigm shift is changing dramatically in the Philippines. With this, teachers' roles are critical in ensuring that students learn successfully. The occurrence of the COVID-19 put schools, teachers, students, parents, and other stakeholders to the test. Many school districts moved activities online in order to maintain instruction even when schools were closed (Organization for Economic Co-operation and Development, 2020). Aside from online learning, most public schools especially in remote areas employed modular instruction through printed self-learning modules. Additionally, most students (Cos et al., 2021; Manlangit et al., 2020) and parents opted the modular distance learning among other alternative modalities. As a result, teachers' capacity to give high-quality training and preparation for students deteriorated. The pandemic drove teachers with a crucial role in facilitating and monitoring the student's development despite any challenges and changes in the educational platform, where learning occurs at home. Nevertheless, quality learning experiences do not occur only within the four walls of the classroom; learning can occur at any time and from any location (Pentang, 2021c).

Teachers face different challenges due to these abrupt changes in the new educational system. Modular instruction, as an alternative modality for learning continuity, resulted in various challenges. Still, teachers must keep track of their students' development and monitor the progress of their students. When feasible, the teacher should visit students at home who need remediation or help (Llego, 2021). On a regular basis, difficulties in applying the distance learning strategy developed. Dangle and Sumaoang (2020) asserted that the key challenges that occurred were the shortage of school finances in the creation and delivery of modules. Cardullo et al. (2021) added that teachers were caught off guard for emergency remote instruction owing to a lack of distant education expertise as well as computer literacy. Indeed, 
the pandemic tests the teachers' flexibility and adaptation in times of crisis. As a result, it motivates them to come up with innovative ways to interact with their learners. Teachers underwent training to equip them to provide better teaching in the face of the COVID-19 threat. Still, teachers cannot simply ignore uncontrolled circumstances (Lagua, 2020). Despite the challenges, educators continue to make learning possible, doing everything they can to acclimate to the new normal.

One of the teachers' abilities is to adapt in the face of adversity. Different challenges arise, particularly during this difficult time, and teachers are still adjusting to the new normal. As a result, teachers employ a variety of coping strategies to deal with the difficulties they face. These coping mechanisms assist teachers in overcoming challenges and are a great help in improving the situation. With the foregoing facts and observations added by the lacuna in the literature concerning the experiences of schools in El Nido Del Norte in the province of Palawan, Philippines towards modular distance learning, this study determined the challenges encountered by high school teachers. It also described their coping mechanisms, which will aid in the resolution of issues that may arise during the implementation of the new normal alternative learning system. Lastly, it seeks to suggest a plan of action to avoid these challenges based on the participant's coping mechanism.

\subsection{Significance of the Study}

Students will be reassured that their teachers are genuinely concerned about them. Besides, teachers can be provided with encouragement and a positive outlook in the face of challenges brought about by the paradigm shift in the educational system. It will assist teachers in becoming more aware of potential issues that they may face in the new normal and prepare them for such situations and enable them to come up with alternative solutions to their problems. Furthermore, the findings will allow schools to conduct orientations and training to address the issues raised while the governing bodies will be informed of the trends pertaining to struggles among high school teachers.

\subsection{Objectives of the Study}

The study explored the experiences of high school teachers with modular instruction using printed selflearning modules. Specifically, the study:

a. determined the challenges encountered by the teachers with respect to modular learning;

b. described the coping mechanisms employed by the teachers to overcome their struggles; and

c. proposed a plan of action arising from the challenges and coping mechanisms reported.

\section{LITERATURE REVIEW}

\subsection{Education in Time of Pandemic}

Teachers in the new normal face challenges brought by the COVID-19 pandemic which posted rapid adjustments in the educational system (Alvarez, 2021; Anzaldo 2021; Castroverde \& Acala, 2021), including parents of the students (Guiamalon et al., 2021; Kintanar et al., 2021; Pascual, 2021). Even though other countries have already been rid of the virus's menace, the Philippines remains one of the most seriously hit. The pandemic has a significant impact on education in the country, where academic institutions and schools encounter major adjustments. The pandemic caused hindrances to face-to-face education (Abbas, 2021; Cos et al., 2021). The education sectors work together to ensure the continuity of education and that every school continues to achieve its goal and vision of providing excellent education to every Filipino student (Dangle \& Sumaoang, 2020). As a result, the Department of Education (DepEd) instituted DepEd Order No.12 series of 2020, which formulated new learning delivery modalities at all levels, as represented in the Learning Continuity Plan (LCP) for the school year 2020-2021 up to the present (Guiamalon et al., 2021). Different learning modalities presented include online distance learning, blended learning, homeschooling, and modular distance learning in digital or printed format. Among the different modalities offered, the use of printed self-learning modules is the method used by most public schools. It is because only a few learners, especially in remote areas can access the internet since only a few have gadgets and there is a limited internet connection.

\subsection{Teachers in Time of Pandemic}

Teachers play a crucial role in ensuring that students get the most out of the modules that are delivered to them during the pandemic. Tosun et al. (2021) noted the lack of experience among teachers towards the current situation. Regardless of any circumstances, Pentang (2021c) stated that teachers must use available and applicable pedagogy to effectively deliver their lessons. Despite the challenges posed by the COVID-19 pandemic, teachers continue to serve by developing modules that act as students' learning guides (Lapada et al., 2020). However, Malipot (2020) stressed that teachers also air their problems on modular distance learning such as: reproduction costs and being forced to attend school as late as 11:00 p.m. to complete the printing on time. Macaraeg et al. (2021) mentioned that the country's Teachers Dignity Coalition claimed that modular distance learning has created extra workload, health risks, and additional expenses which causes teachers to beg for donations of bond paper and ink to print. These only evidently show that challenges really do exist in the 
use of printed self-learning modules. Despite challenges that may impede their work, teachers manage to cope with the new normal and complete their tasks (De Villa \& Manalo, 2020).

To verify the findings and insights above, this study was carried out to picture the realities and trends concerning the challenges and coping mechanisms of high school teachers in El Nido Del Norte, Palawan Palawan, Philippines.

\section{METHODOLOGY}

\subsection{Research Design}

The study employed a qualitative research design to determine the challenges encountered and coping mechanisms employed by the teacher-participants. It was deemed necessary that an in-depth inquiry is appropriate to record the teachers' challenges and coping mechanisms as the pandemic continually posed shifts in the educational system. In addition, a qualitative approach is essential with the limited number of participants who are available and willing to share their stories.

\subsection{Participants and Sampling Procedure}

Participants of the study were 10 secondary teachers from five public high schools in El Nido Del Norte in the province of Palawan, Philippines. Employing a nonprobability availability sampling, each school has two volunteers who participated in the study, based on their availability, willingness, and voluntarism. The participants freely completed and signed a consent form while their personal information and school details were treated with utmost confidentiality and anonymity.

\subsection{Data Gathering and Analysis}

An approved request letter from authorities and a consent form were secured from the participating schools and volunteer teachers. To maintain anonymity, the names of the institutions and teachers who participated were kept unknown all throughout the manuscript. Besides, all participants were oriented about the purpose of the study. Having complied with all the required preliminaries, data were gathered from December 2021 to January 2022.

Data were gathered through an open-ended narrative that allows the participants to share their experiences towards modular instruction or self-learning modules highlighting two key points, (a) challenges encountered and (b) coping mechanisms employed. This scheme was implemented with the rising cases of COVID-19 in the locality where face-to-face interaction is not possible whereas online interview was not also an option with the intermittent power interruption and poor internet connectivity. This confirms that possible procedures can be employed to learn from the experiences of the teachers which is necessary for the current study.

The researchers use the following approach to analyze the data collected: (1) thoroughly read the narratives of each participant; (2) extract substantial statements; (3) formulate meanings; (4) organize the collection of meanings into themes; (5) interpret the themes and; and (6) give recommendations. The researchers interpreted the stories shared in everyday life in the same way that narrative analysis is done (Magulod et al., 2021).

\section{RESULTS \& DISCUSSION}

\subsection{Challenges Encountered}

The COVID-19 pandemic put the educational system to the test where teachers encountered various challenges. The result revealed that teachers in the secondary schools in El Nido Del Norte came across different challenges in teaching using the printed selflearning modules amid the COVID-19 pandemic.

Theme 1: Quality learning. Due to a variety of circumstances, teachers had difficulties in the transfer of quality learning. It was revealed that teachers were challenged in validating the performances of their students. From the narrative, "teachers cannot monitor and evaluate the actual progress of the students". Assessing and engaging students are crucial issues in these times (Khlaif et al., 2021). With today's mode of instruction, it is really a challenge to validate students' output and performance. In addition, Anzaldo (2021) claimed that not all learners do their modules committedly and without the presence of teachers and classmates who remind them of their work, students are more likely to become sidetracked and lose sight of deadlines. Particularly, given the lack of face-toface lectures and the fact that they were only using modules on their own. Akin to Pentang et al. (2020), learners who independently worked on their modules do not fully guarantee quality learning.

Another concern was found in the study. Parents are the ones answering the modules. Parents' writing was recognized by the teachers. As it can be noted on the participants narrative, "it is evident that the outputs submitted were not from the students but the output of the parent/guardian". Anzaldo (2021) support this claim that parents pamper their children and do their task instead of them. The parent's primary role in modular learning is to establish a connection and guide the child (Manlangit et al., 2020), however, it is alarming that they go beyond this role. 
Parallel with Castroverde and Acala (2021), teachers were also challenged with the late submission of outputs and the number of response sheets that students passed with incomplete answers, "there were lots of late submissions and lacking/missing entries". This may be due to the numerous tasks provided in each module. Similarly, Olivo (2021) showed that parents perceived that modular distance learning was generally implemented well except for the learning activities which they claimed were too many to complete in a given time period. Dangle and Sumaoang (2020) agreed that the great number of activities in each module is one of the main problems that emerged in the implementation of modular distance learning. Thus, it is reasonable to assume that this is one of the reasons why students were not able to complete their answers or even late in the submission.

Theme 2: Distribution and retrieval of modules. The teachers expressed their struggles with module distribution and retrieval as a result of the elements that contribute to this load. The findings resulted that teachers were challenged because of the lack of resources, "we do not have ample resources, printers, bond papers, etc.". In these difficult times, printers play an important role in enabling instructors to print modules. However, the teachers do not have access to printers. As a result, several teachers utilized their own money to purchase one for their classes, "we spent from our own pocket". Likewise, Tagupa (2018) mentioned that teachers are frequently forced to spend their own wages on necessities that they should not be shouldering. Another issue for teachers was when modules were not posted on time. The teachers rely on modules to be downloaded from the regional or national level, "we have a hard time securing a copy". Anzaldo (2021) emphasized that perhaps they might produce the module sooner to assist teachers in completing their weekly home learning plans. When uploads are delayed, teachers must construct their own instructional activities for their learners. Thus, increasing the teacher's workload. Aside from these concerns, teachers showed displeasure when students failed to claim modules on time, "we prepared the modules on time, so we expect it to be distributed on time too". Despite the difficulties of purchasing their own printer and designing their own modules in order to continue assisting students, they will be confronted with the truth that there are still students who were late in claiming modules. It is an additional hardship since it merely adds extra work to the teachers because they will have to wait for late outputs, which means they will not be able to compute their grades. Furthermore, there are students who were late in submitting answer sheets. Teachers were challenged because of the deadline for the submission of grades, "we have compliances too, teachers have to submit their reports on time". Another aspect is that a teacher has limited time to wait due to the numerous activities indicated in the module that must be completed. Accordingly, Dangle and Sumaoang (2020) reported that one of the primary challenges that occurred in the implementation of modular distance learning was many activities in each module. Thus, this could be one of the reasons why retrieval of modules was not being completed on time, which may also contribute to the student's poor performance.

\section{Theme 3: Students difficulty in following} instruction. The teachers were challenge with the student's difficulty in understanding modules instruction, "instructions were clear and simple, why do they rely on a long and repetitive one as practice during face-to-face classes". This was evident too in the study of Alvarez (2021) where students were confused regarding the instructions indicated in their modules. This may be due to the poor reading comprehension ability of the students. Regardless of what instruction the teacher may use, reading comprehension difficulty will be a hindrance to student's development (Abbas, 2021). In this regard, teachers are encouraged to consider developing the comprehension ability of the students since the printed modules requires reading.

Theme 4: Power interruption and internet connection. The teachers aired the challenges in terms of (a) power interruption since teachers who utilized $\mathrm{Wi}-\mathrm{Fi}$, which is powered by electricity were greatly affected since they rely on power supply to finish their tasks such as charging their laptops and printing modules. Aside from causing work delays, it may also cause harm to electronic devices in the worst-case situation (b) teachers were also hampered by poor and inconsistent internet connections, as teachers depend on strong internet connections to interact with their learners, "we experience intermittent power interruption and no/unstable internet connection, it disrupts our preparation for the modules and communication with the students with their parents". As a result, teachers traveled to locations with a reliable internet connection. Akin to Tosun et al. (2021), issues such as lack of internet access and infrastructure inadequacies in rural areas hinder learning delivery. With the emergence of technology in teaching-learning as well as unprecedented challenges (Pentang, 2021b), teachers are encouraged to implement innovative programs to support not only learning continuity but also the delivery of quality education with the support of school administrators. This calls the attention too of the local government unit, electric cooperatives, and telecommunication companies to support the educational sector of the country. 
Theme 5: Health risks. The teachers were challenged with the health risk in distributing and retrieving modules, "we have co-teachers who were infected by COVID-19". Despite the risk that threatens their lives, teachers continued to serve and teach students to provide quality education for the learners. Indeed, teachers have no choice but to do their jobs regardless of any circumstances, "this is our profession and we made it our passion, we still have to go out and serve our students". This proves the commitment and dedicated service of the teachers despite the fears of getting infected by COVID-19. Even during the pandemic, commitment, dedication, and a passion for clients and service remained (Pizaña et al. 2021).

\subsection{Coping mechanisms}

Despite the challenges mentioned, the teachers were able to cope with modular instruction, similar with De Villa and Manalo (2020). This demonstrates the teachers' flexibility, adaptability, and innovativeness. Six emerging themes were identified among the coping mechanisms.

Theme 1: Money Matters! The teachers claimed that they spent their own money in order to cope with the lack of resources. Teachers 5, 6, 9, and 10 expressed, "...limited resources were among the major problems, to cope with this, I used my own money to compensate for what is needed...". Likewise, teacher 4 stated, “...when there is a shortage of school materials, I just willingly provide it using my own money...". Teacher 8 added, "...if no available materials, self-provide...". Teachers have no choice but to find ways to prepare learning materials especially printed modules. Sadly, Tagupa (2018) noted that teachers must handle these themselves or their ratings would suffer. Money matters, indeed, not for teachers to spent personally, but for them to serve their students.

Theme 2: Find Ways! The teachers modify the activities to suit the learner's needs. They craft activities aligned with the most essential learning competencies when there is no available module. Teachers 4,5 , and 6 stated, "...if modules are still not available, making simple activity sheets that are aligned with the competencies of the subject is necessary...”. Further, teacher 1 shared, “...I reduce the learning activities by assigning activities that will only meet the competencies...". In addition, teacher 2 claimed, "...I craft my own module using the approved most essential learning competencies...". These manifest how flexible and creative Filipino teachers are. Guiamalon et al. (2021) advanced that teachers should develop an appropriate strategy and continue to apply adequate measures to satisfy the need for new normal education, such as making their own modules or activities when needed. Hodges et al. (2020) further stated that due to the present health issue, many educators have been forced to invent short online learning solutions. Evidently, teachers find ways in all circumstances, subjecting themselves beyond what is required and expected of them.

Theme 3: I-n-t-e-r-n-e-t! The teachers secure a place where the internet connection is fast and stable. Teachers 2, 5, and 7 expressed, "...I travel to other location just to have good internet connection...sometimes, we share from the Wi-Fi of our friends or neighbors to get online...". Besides, Teachers 4, 8, and 9 shared, “...when there is a need to connect to the internet, I go to a place with a good internet connectivity...". I-n-t-e-r-n-e-t, despite the connectivity being shattered, teachers always do their best to connect to the internet to download learning resources as well as to connect with their students. Teachers who go long distances merely to teach and find an internet signal for their online lessons need to be respected and honored (Olivo, 2021).

Theme 4: Communicare! The teachers communicate with care (communicare) the students to clarify concerns regarding their modules as well as to remind parents about their role. Teachers 4, 8, and 9 claimed, "...when it comes to giving instruction to the students...I do it personally upon distribution of modules then I will follow-up through chats...". Besides, Teachers 5, 6, and 7 stated, “...aside from written instruction, If I have a chance, I tell personally the instruction, I find time to text or call them...". Teacher 2 added, “...I speak their language, I give instruction in Cuyonon if the student is a Cuyonon...". Students struggled to answer their modules because it is modular and self-paced learning, given that some children, including their parents, have no one to turn to for assistance. Teachers 3, 5, and 6 stated, “...tap parents through home visitation...parent-teacher meetings to guide their children and prioritize their evaluation for their better future...". Furthermore, Teacher 2 shared, “...Advise parents to avoid spoiling their children, only facilitate but not the one to answer the modules...". Likewise, Teachers 4 and 9 agreed, “...informing parents for their duty as parents through orientation, homeroom limited/face-to-face and home visitation...". Indeed, parental assistance is essential, especially in this new normal. Communicare with parents is a strong mechanism for teachers to assure that the students are doing well. Pascual (2021) mentioned that teachers can support parents by suggesting an adjustment in a daily routine of a child at home which can foster a child's literacy development. Parents can serve as mentors, tutors, and guides to their children. Pentang (2021a) demonstrated that careful mentoring, tutorials, and assistance can improve the performance of home-schooling students who work with their modules under limited supervision. 
Theme 5: Moni-tour! The teachers monitor and toured (tracked) students' development and performance using answer sheets, retrieve modules, and feedback forms. Teachers 4 and 8 stated, “...I monitor my students' progress through their outputs and performances...". Teacher 7 added, "...I base their progress on the retrieved outputs and their attitudes in claiming or passing modules...". Similarly, Teacher 9 mentioned, “...I monitor through checking their activities and summative test...". With no face-to-face interactions to help students, it is critical to moni-tour and evaluates their progress. If not observed, teachers may be astonished to realize that students are not interested in doing or responding to their modules. Since student monitoring and assessment of learning is difficult in today's educational setting (Baryam, 2021), it is critical to rigorously validate the student's work. Still, the teachers were able to make time and double the effort to cope in monitoring and evaluating students' learning.

Theme 6: Time's Up! The teachers remained consistent in setting the schedule for the distribution and retrieval of modules. Teachers 2 and 8 claimed, "...I remained consistent with the schedule, from time to time I follow up through messenger and other means to reach out my students...". Teachers 3 and 6 added, "...I am constantly reminding my students about the schedule of distribution and retrieval of the printed modules...". Teachers 4 and 5 furthered "...I set time and date for the distribution \& retrieval...I add reminders to the distributed materials...". Before the time is up, the teachers set a good example of time management and constantly encourage the students about the schedules. Accordingly, delays in both distribution and retrieval are reduced. Unfortunately, late delivery of modules by service providers, frequently created stress for teachers since they needed to duplicate the modules themselves for the modular learners (Melorin, n.d.). Still, the United Nations International Children's Emergency Fund (UNICEF, 2020) underlined that it is the responsibility of teachers to ensure that modules are delivered and retrieved on time.

\subsection{Suggested Plan of Action}

In dealing with various challenges that may emerge throughout the teaching process, teachers may have these plans of action.

Safety \& health protocols. Teachers should make it a habit to always practice safety and health protocols to mitigate the spread of the virus as well as not to get infected while performing their function in and out of the school, and they are encouraged to get fully vaccinated.

It is best for schools to install designated handwashing areas, provide hygiene kits for teachers, and limit the entry of clients within the vicinity with stricter implementation of the safety and health protocols.

Lack of resources. Teachers may direct the concerns to the proper authority. They may also look for sponsorships and work on donation drives or fund-raising campaigns, or partner with their co-teachers to minimize the problems pertaining to the printing of modules.

Schools may allot more budget in the production, distribution, and retrieval of modules from their Maintenance and Other Operating Expenses.

Internet connection. Teachers may install $\mathrm{Wi}-\mathrm{Fi}-$ boosters and external antennas. Schools may also provide sufficient load cards to the teachers. Further, the Department of Education may enter with a memorandum of understanding/agreement with the Department of Energy and Department of Information and Communications Technology to support the electrification of remote areas and a establish strong internet connection, respectively, for the schools, teachers, students, and parents to connect and communicate with each other.

Modules. Teachers should double-check downloaded modules before distributing them to the students. In case of no available modules to download, they can create one by referencing the competencies of the subject. Teachers may also provide fewer activities but are still aligned with the necessary competencies.

Giving instruction. Teachers must try to explain in every way possible for students to easily understand the given instruction. Also, teachers must be always open and give chance for the students to raise questions. If possible, provide examples and illustrations to facilitate the students. Since feedback is important (Pentang, 2021a), teachers may further allow both the students and parents to provide theirs.

Monitoring and evaluation. Teachers must keep records of students' accomplished outputs (both formative and summative) and keep them informed of their performance (transparency). Pre- and post-tests may be required where research may take place to help define the progress of the students.

Teachers must recheck provided answer keys to avoid errors. Teachers may also check for plagiarism for essay-type questions. Further, teachers should return the graded outputs of their students. Since monitoring and evaluation are equally important in ensuring quality education and preparing competitive graduates (Kankaew et al., 2021), stricter measures may be implemented by schools and concerned teachers.

Distribution and retrieval of modules. Teachers must be consistent with the schedule. To be efficient, 
distribute modules and retrieved outputs during home visits. More importantly, ensure the completeness of entries and details before allowing the students to submit. With the technological advancements in education with the continuing development in educational technologies as teaching-learning tools (De Souza et al., 2021; Pentang, 2021b), teachers may explore online and offline tools to facilitate the distribution and retrieval of modules.

Parent's support. Teachers must earn the support of the parents and partner with them to help the students learn with their modules. It is best to involve them in classroom conferences and keep them informed of the student's progress in school. The whole community may take part too (Capulso et al., 2021).

\section{CONCLUSIONS \& RECOMMENDATIONS}

The findings of the study found varying degrees of challenges that teachers experienced in implementing printed self-learning modules. Learning about the result of this study will help teachers to overcome problems arising regarding the ongoing shift in education. Teaching can be challenging at times especially in these trying times, but just like how these teachers addressed the challenges they faced, all is possible. Teachers dealt with these difficulties by employing their own coping techniques. Even though they have experienced such obstacles, the good news is that as educators, they still looked for possible solutions to solve the issues.

Based on the findings and conclusions, the researchers suggest that teachers should always bear in mind the safety and health protocols. Teachers should devise strategies to address the issue of material scarcity. Teachers should design instructional activities that are tailored to the requirements of their students. The school should have reliable and consistent internet access. Teachers should connect with their students or parents and give feedback on their performance. Teachers should constantly evaluate their students' growth. Lastly, teachers must be prepared for any eventuality that may develop.

This situation will not soon return to normal, but rather it is more like teachers are in need to adjust and accept the circumstance. This necessitates the presence of extension projects from state universities and colleges (Pentang, 2021a; Pentang et al., 2020; Pizaña et al., 2021) as well as non-government higher education institutions, where they play an important role in extension activities and outreaches by conducting series of tutorials and distributing learning materials to the students to supplement the instruction provided by teachers. A homeschool link program (Kintanar et al., 2021) may be established to teach parents about effective modular distance learning at home.

\section{LIMITATIONS}

We considered the study's small sample size of only ten participants to be a disadvantage. The researchers recommend that future studies increase the number of participants and widen the scope of the locale in order to validate the results. With the use of narratives as an innovative way to obtain data during the pandemic, the researchers strongly recommend adopting such a method for researchers who have difficulty in conducting online or face-to-face interviews or focused group discussions.

\section{ACKNOWLEDGEMENTS}

The researchers are grateful to the schools and teachers who participated in the study, as well as the guidance from the Department of Education - El Nido Del Norte District with the Western Philippines University Puerto Princesa Campus.

\section{CONFLICT OF INTEREST AND FUNDING}

The researchers do not have any contending interests. The study was personally funded by the researchers.

\section{REFERENCES}

[1] Abbas, K. D. A. (2021). Factors influencing students reading comprehension difficulties amidst the use of modular distance learning approach in Mindanao State University Sulu - Senior High School. Open Access Indonesia Journal of Social Sciences, 4(6), 447. https://doi.org/10.37275/oaijss.v4i2.78

[2] Alvarez, M. (2021). Issues and concerns of teachers in Mindanao State University-Sulu towards modular distance learning approach: An analysis. Indonesian Community Empowerment Journal, 1(2), 40-41. https://doi.org/10.37275/icejournal.v1i2.12

[3] Anzaldo, G. D. (2021). Modular distance learning in the new normal education amidst Covid-19. International Journal of Scientific Advances, 2(3), 263-266. http://dx.doi.org/10.51542/ijscia.v2i3.6

[4] Bayram, H. (2021). Challenges secondary school teachers face during the distance education process. International Journal of Eurasian Education and Culture, 6(12), 613-658. http://dx.doi.org/10.35826/ijoecc.306

[5] Capulso, L. B., Magulod, G. C., Jr., Nisperos, J. N. S., Dela Cruz, J. M. M., Dizon, A. M., Ilagan, J. B., Salise, G. C., Vidal, C. J. E., Pentang, J. T., \& Dugang, M. A. P. (2021). The teacher and the community, school culture and organizational leadership. Beyond Books Publication. 
[6] Cardullo, V., Wang, C., Burton, M., \& Dong, J. (2021). K12 teachers' remote teaching self-efficacy during the pandemic. Journal of Research in Innovative Teaching and Learning, 4(1), 32-45. https://doi.org/10.1108/JRIT-102020-0055

[7] Castroverde, F., \& Acala, M. (2021). Modular distance learning modality: Challenges of teachers in teaching amid the Covid-19 pandemic. International Journal of Research $\begin{array}{llll}\text { Studies in } & \text { Education, } & \text { 10(8), }\end{array}$ https://doi.org/10.5861/ijrse.2021.602

[8] Cos, F. L., Duero M. C., \& Paguia, M. R. S. (2021). The viability of DepEd textbooks as the primary material for the modular distance learning modality of Carrascal National High School. Journal of Innovations in Teaching and Learning, 1(2), 69-75. http://www.sciepub.com/JITL/abstract/13265

[9] Dangle, Y. R. P., \& Sumaoang, J. D. (2020). The implementation of modular distance learning in the Philippine secondary public schools. In 3rd International Conference on Advanced Research in Teaching and Education, 100 , 108 . https://www.doi.org/10.33422/3rd.icate.2020.11.132

[10] De Villa, J. A., \& Manalo, F. K. B. (2020). Secondary teachers' preparation, challenges, and coping mechanism in the pre-implementation of distance learning in the new normal. IOER International Multidisciplinary Research Journal, 2(3), 144-154. http://dx.doi.org/10.5281/zenodo.4072845

[11] De Souza, R., Parveen, R., Chupradit, S., Velasco, L. G., Arcinas, M., Tabuena, A. C., Pentang, J. T., \& Ventayen, R. J. M. (2021). Language teachers' pedagogical orientations in integrating technology in the online classroom: Its effect on students motivation and engagement. Turkish Journal of Computer and Mathematics Education, 12(10), 5001-5014. https://turcomat.org/index.php/turkbilmat/article/view/5268

[12] Guiamalon, T. S., Alon, S. A. S., \& Camsa, S. U. (2021). Teachers issues and concerns on the use of modular learning modality. International E-Journal of Advances in Social Sciences, $\quad 7(20), \quad 457-469$. http://dx.doi.org/10.46529/socioint.202115

[13] Hodges, C., Moore, S., Lockee, B., Trust, T., \& Bond, A. (2020, March 27). The difference between emergency remote teaching and online learning. Educause. https://er.educause.edu/articles/2020/3/the-differencebetween-emergency-remote-teaching-and-online-learning

[14] Kankaew, K., Beltran, J. A., Khamidullina, Z., Magulod, G. C., Jr., Capulso, L. B., Cabacang, G. S., Anh, V. T., Vela, L. A. P., \& Pentang, J. T. (2021). Immediate program learning outcomes of information technology candidates and their introspections towards IT education relevance and global competence initiatives. Psychology and Education Journal, $58(2)$,

5417-5427.

http://www.psychologyandeducation.net/pae/index.php/pae/ article/view/2953

[15] Khlaif, Z. N., Salha, S., Affouneh, S., Rashed, H., \& ElKimishy, L. A. (2021). The Covid-19 epidemic: Teachers' responses to school closure in developing countries.
Technology, Pedagogy and Education, 30(1), 95-109. https://doi.org/10.1080/1475939X.2020.1851752

[16] Kintanar, F. C., Elladora S. T., \& Cuizon F. R. (2021). Plight of the parents of the Filipino learners in the implementation of the modular distance learning. International Journal of Educational Science and Research, $11(2)$, 35-48. http://www.tjprc.org/view_paper.php?id=15421

[17] Lagua, B. (2020, October 30). Teaching in the new normal. The Manila Times. https://www.manilatimes.net/2020/10/30/business/columnist s-business/teaching-in-the-new-normal/788762

[18] Llego, M. A. (2021). DepEd learning delivery modalities for school year 2020-2021. TeacherPH. https://www.teacherph.com/deped-learning-deliverymodalities/

[19] Magulod, G. C., Jr., Capulso, L. B., Delos Reyes, R. J. V., Luna, A. R. F., Orte, C. J. S., Maglente, S. S., Pentang, J. T., Olitres, B. J. D., Vidal, C. J. E., \& Samosa, R. C. (2021). How to write and publish your thesis. Beyond Books Publication.

[20] Malipot, M. H. (2020, August 4). Teachers air problems on modular learning system. Manila Bulletin. https://mb.com.ph/2020/08/04/teachers-air-problems-onmodular-learning-system/

[21] Manlangit, P., Paglumotan, A. M., \& Sapera, S. C. (2020, October 5). Nanay, handa na ba kayong maging tagapagdaloy? Supercharging Filipino parents is key for successful modular distance learning. Flip Science. https://www.flipscience.ph/news/featuresnews/tagapagdaloy-modular-distance-learning/

[22] Melorin, M. (n.d.). Module distribution and retrieval: A challenge. Schools Division Office - San Juan City. https://www.depedsanjuancity.ph/single-post/moduledistribution-and-retrieval-a-challenge

[23] Olivo, M. G. (2021). Parents' perception on printed modular distance learning in Canarem Elementary School: Basis for proposed action plan. International Journal of Multidisciplinary: Applied Business and Education Research, 2(4), 296-309. http://dx.doi.org/10.11594/ijmaber.02.04.03

[24] Organization for Economic Co-operation and Development. (2020, September 24). Strengthening online learning when schools are closed: The role of families and teachers in supporting students during the Covid-19 crisis. Organization for Economic Co-operation and Development. http://www.oecd.org/coronavirus/policyresponses/strengthening-online-learning-when-schools-areclosed-the-role-of-families-and-teachers-in-supportingstudents-during-the-covid-19-crisis-c4ecba6c/

[25] Pascual, E. A. (2021). Parent-teacher-learner collaboration in modular distance learning. International Journal of Research Publications, 83(1), 189-202. https://doi.org/10.47119/IJRP100831820212196

[26] Pentang, J. T. (2021a). Impact assessment and clients' feedback towards MATHEMATICS project implementation. International Journal of Educational 
Management and Development Studies, 2(2), 90-103. https://doi.org/10.53378/346107

[27] Pentang, J. T. (2021b). Technological dimensions of globalization across organizations: Inferences for instruction and research. International Educational Scientific Research Journal, 7(7), 28-32. https://dx.doi.org/10.2139/ssrn.3896459

[28] Pentang, J. T. (2021c). The concept of curriculum and its foundation. The Educator's Link, 1(6), 9. https://www.researchgate.net/publication/355953574_The _ Concept_of_Curriculum_and_its_Foundation

[29] Pentang, J. T., Bautista, R. M., Pizaña, A. D., \& Egger, S. P. (2020). Mathematical needs of Laura Vicuña learners. Western Philippines University Graduate Journal, 5(1), 7882. https://ssrn.com/abstract=3980365

[30] Pizaña, A. D., Pizaña, R. E. C., Pogoy, A. M., \& Pentang, J. T. (2021). Lived experiences of extension project implementers amidst COVID-19 pandemic: The unspoken frontliners. European Scholar Journal, 2(4), 431-436. https://scholarzest.com/index.php/esj/article/view/648

[31] Tagupa, H. (2018, June 29). Are PH teachers really underpaid? Inquirer.net. https//: https://opinion.inquirer.net/114243/ph-teachers-reallyunderpaid

[32] Tosun, N., Mihci, C., Bayzan, S. (2021). Challenges encountered by in-service K12 teachers at the beginning of the Covid-19 pandemic period: The case of Turkey. Participatory Educational Research, 8(4), 359-384. http://dx.doi.org/10.17275/per.21.95.8.4

[33] UNICEF (2021, September 14). Classroom precautions during COVID-19: Tips for teachers to protect themselves and their students. United Nations International Children's Emergency Fund. https://www.unicef.org/coronavirus/teacher-tips-classroomprecautions-covid-19 